\title{
Organisational Justice: Migrant Worker Perceptions in Organisations in the United Arab Emirates
}

\author{
Kasim Randeree \\ The British University in Dubai, United Arab Emirates
}

\begin{abstract}
A justice framework can be used to understand how individuals within organisations respond to a variety of human resource practices and also can be used prescriptively in designing the procedures and enactment of human resource practices. The principles of justice can be applied in order to understand the consequences of any human resource practice. This paper examines the impact of the perception of organisational justice on job satisfaction of unskilled workers in the city of Dubai in the United Arab Emirates (UAE). The key findings of the research revealed Dubai as having the largest proportion of expatriate workers globally and that these employees present a high level of grievance towards their employers. Major issues highlighted by the survey include pay, workload, job responsibilities, bias, and employer injustice.
\end{abstract}

\section{Keywords}

Organisational Justice, Migrant Worker, Job Satisfaction, Job Performance, Equity, Ethics.

\section{Introduction}

Organisational justice is concerned with fair treatment of employees and is considered to encompass three different components - distributive justice, procedural justice and interactional justice.

Distributive justice refers to the concerns expressed by employees with regards to the distribution of resources and outcomes (Greenberg, 1990; Cropanzano and Folger, 1989). The employee's perception of whether the outcome is fair or otherwise forms the basis of the concept of distributive justice. It is the individual within an organisation who determines the fairness of the distribution through comparison with others. The employee is concerned about the equity aspect of justice; does the individual think that they are treated fairly in terms of work load, work schedule, salary, bonuses or promotion.

Procedural justice is the perceived fairness of procedures which are used to determine outcome decisions (Folger and Konovsky, 1989). These procedures should be consistent, bias free and take into account the concerns of all parties and be morally acceptable (Leventhal, 1980). Here the employee is concerned about whether the decision process is fair and the process used to determine the outcome was just. It is

Copyright (C) 2008 Victoria University. This document has been published as part of the Journal of Business Systems, Governance and Ethics in both online and print formats. Educational and non-profit institutions are granted a nonexclusive licence to utilise this document in whole or in part for personal or classroom use without fee, provided that correct attribution and citation are made and this copyright statement is reproduced. Any other usage is prohibited without the express permission of the mainly concerned with the fairness of the means that an organisation uses to determine outcomes.

Interactional justice relates to the fairness of interpersonal communication in respect to organisational procedures (McDowall and Fletcher, 2004). It is concerned with how the information was communicated and whether the individuals affected by a decision were treated in a courteous and civil manner (Bies 
and Moag, 1986), such as being treated with respect and dignity. These three concepts of organisational justice will be used to study their impact on unskilled workers in Dubai. Detailed analysis of these have been carried out in an earlier study (Randeree and Malik, 2008).

The focus of the study is more than the theoretical view on justice. This study is concerned with individuals' responses to the things they receive (that is, the outcomes), and the means by which they obtain these outcomes. This research uses the organisational justice measures developed by Niehoff and Moorman (1993) to test their impact on job satisfaction.

This study draws light on two major issues

(a) Measures of job satisfaction in relation to outcomes (distributive justice), the fairness of employers' decisions processes (procedural justice) and communication methods (interactional justice.

(b) The potential impact of the perceptions of organisational justice on self-percieved performance of employees, specifically unskilled workers

The organisational justice models listed below selected based on the criteria that these encompass all kind of workers, unskilled and skilled. Other organisational justice models which addressed only skilled workers were omitted from this study. Moreover, there is limited research available focusing exclusively on unskilled workers and hence there was no specific organisational justice model found that relates solely to unskilled workers.

Because this is a subject which is usually traded-off for pressing productivity and demanding competition, this paper draws on existing research and identifies the knows issues told through each form of justice and its perception in the UAE discovered through the collective view of unskilled workers. The study aims to reveal how unskilled workers perceive organisational justice, taking example in the city of Dubai in the UAE.

\section{Review of Extant Literature}

Fischer and Smith (2004) studied performance and seniority-based allocation criteria in the UK and Germany. Allocations based on work performance and seniority were perceived to be fair. Work performance accounted for about 11 per cent of the variance in justice perceptions. Lee (2000) explored the relationships between organisational justice, job satisfaction, organisational commitment, and turnover intentions in the lodging industry. The results indicated that distributive justice and procedural justice have direct positive influence on job satisfaction. He concluded that distributive justice plays a more vital role in employees' work-related outcomes than procedural justice and that the impact of interpersonal working relationships on employees' justice perceptions is significant. That is, the quality of interpersonal working relationships promotes employees' perceptions of fairness.

Stark et al. (2000) studied downsizing and layoff survivors in the USA. They reported that while there is some evidence that survivor perceptions of procedural justice might influence job satisfaction, the presence of a strong interaction effect between the negative effect and the perception of psychological contract violation makes it difficult to accurate assess such a relationship.

Robinson (2004) investigated the role of organisational justice in predicting four organisational outcome variables, namely, job satisfaction, organisational commitment, motivation, and performance. As hypothesised, the three components of organisational justice were significant predictors of the four organisational outcome variables. Distributive justice accounted for the most variance in job satisfaction, while procedural justice accounted for the most variance in organisational commitment, motivation and performance.

Aryee et al. (2004) examined the relationship between organisational politics and procedural justice and their influence on exchange fairness and employee performance. Results revealed procedural justice but not organisational politics to be related to task performance and the contextual performance dimensions of interpersonal facilitation and job dedication. 
Cohen and Spector (2001) meta-analysed (carried out quantitative analysis of several separate but similar studies in order establish statistical significance) the role of justice in organisations. They found similar relations among all justice types and satisfaction. The study also reported that job performance and counter productive work behaviours, considered to be outcomes of perceived justice, were mainly related to procedural justice. Since most satisfaction measures were similarly related to all justice types, Cohen and Spector (2001) concluded that to maintain employees' satisfaction, managers should take care that distributions, procedures and interactions will all be fair.

Tang and Sarsfield-Baldwin (1996) attempted to identify the major components of distributive and procedural justice and how they are related to some organisational variables. They identified five factors of procedural justice: fairness, two-way communication, trust in supervisor, clarity of expectations and understanding of the performance appraisal process. Distributive justice was found to be a onedimensional variable. Tang and Sarsfield-Baldwin found distributive justice to be significantly related to satisfaction with pay, promotion and the performance appraisal. Further, different aspects of procedural justice were found to be related to satisfaction with supervision, self reported performance appraisal rating and performance appraisal. They argued that both distributive and procedural justice are important in predicting employees' subsequent personal satisfaction and commitment to the organisation. Using organisational justice analysis, Tang and Fuller (1995) tested job satisfaction in joint venture hotels in China. Unlike interactional justice, both procedural justice and performancebased distributive justice were found to be predictive of job satisfaction.

\section{Migrant Workers in the United Arab Emirates (UAE)}

The recruitment of migrant unskilled workers begins in their home countries. Commonly, local recruitment companies in the source countries, working on behalf of UAE-based companies, advertise for and enlist workers for jobs in the UAE. Construction companies go further, dispatching recruitment scouts directly to source countries to work with local recruitment companies. Others utilise UAE-based recruitment companies to act as intermediaries between UAE employers and recruitment agencies in the source countries. Furthermore, some companies in the UAE, known as manpower supply agencies, import migrant workers for the sole purpose of subcontracting them to other employers, including construction companies, for long- or short-term jobs (Human Rights Watch, 2006a).

The UAE's Labor Law No. 8 of 1980 (the federal law regulating labour relations throughout the country) permits only UAE nationals licensed by the Ministry of Labor to sponsor migrant workers. This applies to employers who directly recruit migrant workers as well as to those companies who act as intermediaries in the recruitment process. Under the UAE Labor Law, employers must pay certain fees to the government for each foreign worker they recruit into the country. These fees include an employment visa request fee of 200 AED (\$55) and an employment visa issuance fee of 1,000 AED (\$273). In addition, employers must provide an airline ticket to migrant workers to travel from their home countries to the UAE.

UAE law explicitly forbids UAE recruiters from collecting any fees from prospective migrant workers. However, UAE recruitment agents appear to openly flout this law, charging workers these fees instead of requiring the prospective employer to bear the cost. Some workers who cannot raise money for the visa fees, resort to taking loans from recruiting agencies at often exorbitant monthly interest rates. The most common complaint from low paid workers in the UAE, which also forms the basis of a large number of labour disputes reviewed by the Ministry of Labor and the Dubai labor agencies is the withholding of wages by employers. The impact on workers whose wages are withheld for even one month is very serious: they immediately fall into arrears on the debt they owe recruiting agencies in their home countries, thus incurring additional interest.

Furthermore, they are unable to send money home to their families who depend on their earned income in the UAE. In some cases, the non-payment of wages means that workers do not have sufficient money to purchase basic necessities. Withholding as much as two months salary as security against workers absconding to a better job is accepted as customary among construction companies in the UAE. There is 
no basis in law for this practice and withholding wages violates UAE law requiring employers to pay workers in a timely fashion and keep verifiable records. In addition, construction companies occasionally withhold wages beyond this two-month security bond when they run into cash flow problems (Human Rights Watch, 2006a).

In a variant of the practice of withholding wages, numerous cases have been reported, where employers change terms of employment without notice, recruiting migrant workers by promising higher wages than they intend paying. For migrant workers, changing jobs within the UAE is a cumbersome, bureaucratic process and requires the consent of the original employer. To begin with, labour regulations require workers to have completed two years of service with their current employer before being entitled to switch employers (Federal Law, 1980). They may seek only the same kind of job, and there must be no UAE national available for the job. Most significantly, in order to move to a new employer, workers must obtain a letter of no objection from their current employer and request the Ministry of Labor to reregister their visa and work permit in the name of the new employer. The fact that employers often hold on to workers' passports, a practice that is also against the law, makes it even more difficult for workers to change jobs. While employers in the UAE are prohibited from confiscating the passports of their employees, employers routinely do this, retaining the passports for the duration of their workers' employment, typically to ensure that the employees do not abscond. By withholding workers' passports, employers exercise an unreasonable degree of control over their workers. Despite the fact that both government officials and UAE courts have reiterated the unlawfulness of this practice, the government has taken only limited steps to enforce this law (Human Rights Watch, 2006a).

Dubai Municipality recorded 34 deaths of construction workers at their workplaces in 2004 and 39 deaths in 2005 (Human Rights Watch, 2006a). Independent research by a construction trade publication, Construction Week, found that a total of 880 migrant construction workers died in the UAE in 2004: 460 from India, 375 from Pakistan and approximately forty-five from Bangladesh, though the report did not provide information regarding the cause of death so it is unclear how many of these were work-related. In the past few years, suicide amongst workers has been on the rise. Accurate and reliable data on the number of suicides is difficult to obtain, though occasional reports of cases of workers committing suicide after allegedly suffering wage exploitation at the hands of his employer are found.

A serious health hazard faced by construction workers is the extreme climatic conditions. The mean maximum temperatures in the UAE during the months of April to September exceed $90^{\circ} \mathrm{F}\left(32^{\circ} \mathrm{C}\right)$, with humidity over 80 percent in coastal areas, notably, Abu Dhabi, Dubai and Sharjah. For construction workers who spend the vast majority of their time working under such conditions, heat-related illnesses are a manifestation of dangerous working conditions. According to Human Rights Watch (2006b), heatrelated illness is the most important health issue facing construction workers. This includes heat-stroke as well as dehydration.

\section{Data and Research Methodology}

In this study, the research strategy involved collection of data through a survey. Firstly, a qualitative approach was adopted as the research aims to gain a deeper understanding and description of a problem (Holme and Solvang, 1991). The decision of a survey was reached based on meeting the three conditions described by Yin (1994), namely, that the type of research questions posed be suited to a questionnaire; a low level of control over behavioural events; and, a high degree of focus on contemporary events and issues.

The population of this study consisted of unskilled workers employed in Dubai in the of construction industry, domestic workers, cargo and freight forwarders and facilities management contractors. A total of 400 questionnaires were distributed and data collection was carried out over a period of six months. The questionnaire was also translated into the Hindi and Tamil languages to facilitate those workers who could not comprehend English language to participate in the research. 
Distributive, procedural and interactional justice was measured by using the scales developed by Niehoff and Moorman (1993). These organisational justice measures were used to test their impact on job performance of unskilled workers in Dubai. Data was collected from employees working in the city of Dubai. Descriptive statistics and correlational analysis were used to examine the data.

The data analysis methodology involved dividing the findings into those related to the impact of distributive justice on job satisfaction of unskilled workers in Dubai; the impact of procedural justice on job satisfaction of unskilled workers in Dubai and; the impact of interactional justice on job satisfaction of unskilled workers in Dubai. Al-Dmour and Awamleh's (2002) tool was then adopted to measure job performance. The findings of this study are representative of the self perceived job performance of unskilled workers in Dubai.

Subsequently analysis was performed and the survey data was cross dimensionally analysed in order to validate the self perceived job performance of unskilled workers in Dubai, this was accomplished by analysing the impact of distributive justice in context of nationality of the unskilled workers and the employer's country of origin. Distributive justice was chosen over the other two types of organisational justice because it is more at a personal level and relates more to the sample of workers under consideration in this research. In terms of distributive justice measures the worker is concerned about the equity aspect of justice; the individual decides whether they have received what they deserve in the form of work loads, work schedules, salary levels, bonuses, promotions, housing allowances. It deals with the workers' perception of whether the outcome is fair. This forms the basis of the concept of distributive justice and it aligns to the research questions. The findings here were then compared to the self perceived job performance of unskilled workers in Dubai in context of employer's country of origin.

The distributive justice scale consisted of five items; examples of this scale are "my work schedule is fair"; "I consider my workload to be fair". The procedural justice scale consisted of five items and listed items such as "job decisions are made by my manager in an unbiased manner", "all job decisions are applied consistently across all affected employees".

The interactional scale consisted of nine items, example of this scale are, "when decisions are made about my job my manager treats me with respect and dignity", "the manager offers adequate justification for decisions made about my job".

The self-assessed performance scale developed by Al-Dmour and Awamleh (2002) was adopted in this study to analyse the Job performance of workers.

The entire set of these scales was included in one questionnaire, the set of questionnaire is provided in the Appendix. They all used a unified five-point Likert scale. The questionnaire included a total of thirty six items written in English.

\section{Results}

\section{Representation of unskilled workers' perception}

Two-hundred-and-twelve questionnaire responses were collected, out of which 192 were used and the remaining excluded for missing data (or other mistakes), resulting in a 48 per cent response rate. Fiftyeight per cent of the respondents were expatriates from the Indian Subcontinent; 84 per cent of the respondents were male; 69 per cent were under thirty years of age and 82 per cent had a debt or financial liability.

To assist analysis, the data was divided into three groups: Workers employed in western organisations, workers in Arab organisations and workers employed in organisations originating in the Indian Subcontinent.

Over 58 per cent of the sample group were nationals of the Indian Subcontinent and nearly 47 per cent of the employees worked for companies from Indian Subcontinent. The expatriate group in the sample 
consisted, by nationality, of Arab nationals, mainly from Syria, Egypt, Sudan, Yemen and Jordan; the Indian Subcontinent, expatriate workers who had migrated from India, Pakistan, Bangladesh, Sri Lanka and Afghanistan and; from the Far East, mainly Indonesia and the Philippines.

The general characteristics of the survey reveal that over 90 percent of unskilled workers in Dubai are foreigners. In overall population statistics, expatriates far outnumber UAE nationals. In the emirate of Dubai, foreigners make up more than 90 percent of the city's 1.5 million residents. Male gender seems to dominate the unskilled worker industry although females from the Far East and from the Indian subcontinent show a significant presence in Dubai as domestic workers. In the income category, over 70 percent of unskilled workers earn US\$200 - US\$300 per month. It was noted that a majority of the unskilled workers from the Indian Subcontinent work for organisations who have their origin in the same region. The survey results also indicated that over 80 percent of unskilled workers in Dubai have a financial debt.

\section{Perceptions of Distributive Justice}

The distributive justice scale consisted of five items; examples of this scale are "my work schedule is fair" and "I consider my workload to be fair." Respondents were asked to mark the extent of the concerns on a scale of one to five. They marked one if they disagreed with Niehoff and Moorman scale and marked five if they agreed.

The analysis of the survey revealed that a majority of employees had grievances towards their organisations, such that 70 percent of workers felt that their work schedule was not fair; almost 75 percent of workers felt that their level of pay was not fair; nearly 65 percent of workers considered their workload not to be fair; over 65 percent of workers believed that the rewards they received for their work were not fair and; nearly 55 percent of workers felt that their job responsibilities were not fair.

\section{Perceptions of Procedural Justice}

The procedural justice scale consisted of five items and listed items such as "job decisions are made by my manager in an unbiased manner", "all job decisions are applied consistently across all affected employees."

The mean analysis of the responses indicated that the majority of job decisions are made by the employer in a biased manner; generally the employer has no interest in finding out employee concerns before a job decisions is made; employers do not clarify job decisions and do not provide additional information when requested by the employee on a majority of job related decisions. It was also found that prevalently, employees are not allowed to challenge or appeal job decisions made by the manager.

\section{Perceptions of Interactional Justice}

The interactional scale consisted of nine items. Examples of items from this scale are, "when decisions are made about my job my manager treats me with respect and dignity", "the manager offers adequate justification for decisions made about my job".

The highlights of the findings reveal that, prevalently, employees felt that managers do not treat them with kindness and consideration in the decision making process; usually when decisions are made, managers do not treat them with respect and dignity; normally when decisions are made, managers are insensitive to their personal needs; commonly, managers are perceived to be dealing in an untruthful manner; usually, managers shows little or no concern for the rights of an employee; in a majority of instances, managers did not discuss implications of job related decisions with their employees; generally, managers do not offer adequate justification for decisions made; managers offer explanations that make little or no sense to employees and; customarily, managers do not explain decisions clearly. 


\section{Self Perceived Job Performance of Unskilled Workers in Dubai}

In order to relate the impact of organisational justice on the job satisfaction and job performance of workers, a tool developed and validated by Al-Dmour and Awamleh (2002) was adopted to access the self-assessed performance scale. This scale is comprised of 5 items including "I consider my performance better than the average employees in my company", and "I always reach my targets".

Using a unified 5-point Likert scale, the mean analysis of the survey revealed that almost 65 percent of employees felt that working conditions do not allow them to perform at high levels; nearly 65 percent of employees also felt that their performance evaluations were not reflecting their abilities; 45 percent of employees considered themselves as very good performers.

\section{Conclusion}

This study of the impact of organisational justice, measured the perceptions of unskilled workers of the three components, distributive justice, procedural justice and interactional justice, and their self assessed performance. The research questions addressed by this study are targeted at understanding how unskilled workers perceive organisational justice, taking example in the city of Dubai in the UAE and the implications on employee job satisfaction and self perceived performance. In addition, the study investigated how the influence of demographic factors within a multicultural work environment impacted employee self-perceived job performance as result of the perception of the organisational justice.

Given the large number of unskilled workforce in the UAE, this study highlighted the need for companies to train and educate their managers as to the impact of the perceived lack of justice on the motivation and commitment of their employees. From the findings of this paper, it can be argued that organisations and employers in the Middle East need to understand the significant role that justice plays in influencing employees' behaviour and work outcomes.

Employers need to examine organisational justice from an employee's point of view and not to rely only on their own assessment and observations. This can be done through meetings, surveys, management by wandering around, employee suggestion systems and adopting an open-door management policy (Kappelman and Prybutok, 1995; Shenhar, 1993). This is likely to help in bridging the perception gap between superiors and subordinates. Furthermore, keeping employees satisfied with their jobs over years is not an easy task, but it is critical for organisational success.

Employers need to understand that the perception of the employee of his/her job, pay, supervisory style, co-workers' relations and promotion opportunities is likely to affect their work outcomes. The outcome of these perceptions (thoughts, feelings and/or actions) are affected by factors outside the employee's control, but they are under the organisational control. Superiors whot talk to their subordinates to gauge how they evaluate and perceive their jobs and what managers can do to improve employees' satisfaction, will benefit from better performance.

Unfortunately, this trend towards employee communication is yet to reach the Middle East. The results of this study suggest that further investigations in this field, in different parts of the region, is needed in order to reach more general conclusions about the nature, significance and levels of justice-work outcomes relationships. This will also help in making cross-cultural comparisons, especially because the perception of justice is likely to be affected by culture. In addition, researchers may investigate the reasons behind the partial mediation of satisfaction in the justice- performance relationship, to find out if there are any other organisational variables that are likely to play a mediation role.

\section{References}

Al-Dmour, H. and Awamleh, R.A. (2002), "Effects of transactional and transformational leadership styles of sales managers on job satisfaction and self-perceived performance of sales people: a study 
of Jordanian manufacturing public shareholding companies", Dirasat: Administrative Sciences Series, Vol. 29 No. 1, pp. 247-61.

Aryee, S., Chen, Z. and Budhwar, P. (2004), "Exchange fairness and employee performance: an examination of the relationship between organizational politics and procedural justice", Organizational Behavior and Human Decision Processes, Vol. 94 No. 1, pp. 1-14.

Bies, R.J. and Moag, J. (1986), "Interactional justice: communication criteria of justice", in Lewicki, R.J., Sheppard, N.H. and Bazerman, M.H. (Eds), Research on Negotiation in Organizations, Vol. 1, JAI Press, Greenwich, CT, pp. 43-55.

Cohen, Y. and Spector, P. (2001), "The role of justice in organizations: a meta-analysis", Organizational Behavior and Human Decision Processes, Vol. 86 No. 2, pp. 278-321.

Cropanzano, R. and Folger, R. (1989), "Referent cognitions and task decision autonomy: beyond equity theory", Journal of Applied Psychology, Vol. 74, pp. 293-9.

Fischer, R. and Smith, P. (2004), "Values and organizational justice performance- and seniority-based allocation criteria in the United Kingdom and Germany", Journal of Cross-Cultural Psychology, Vol. 6, pp. 669-89.

Folger, R. and Konovsky, M.A. (1989), "Effects of procedural and distributive justice on reactions to pay raise decisions", Academy of Management Journal, Vol. 32 No. 1, pp. 115-30.

Greenberg, J. (1990), “Organizational justice: yesterday, today, and tomorrow”, Journal of Management, Vol. 16, pp. 399-432.

Holme, I.M. \& Solvang, B.K. (1991). "Forskningsmetodik - Om kvalitativa och kvantitativa metoder", Lund: Studentlitteratur.

Human Rights Watch (2006a), Middle East Report 2006, viewed 20 October, 2007, $<$ http://hrw.org/mideast/uae.php>.

Human Rights Watch (2006b), Building towers, cheating workers: Exploitation of migrant workers in the United Arab Emirates, Human Rights Watch, Vol. 18 No. 8, p. 41, New York.

Kappelman, L.A. and Prybutok, V.R. (1995), "A small amount of empowerment pays off big in a regional bank", National Productivity Review, Vol. 14 No. 4, pp. 39-43.

Lee, H. (2000), "An empirical study of organizational justice as a mediator of the relationships among leader-member exchange and job satisfaction, organizational commitment, and turnover intentions in the lodging industry", $\mathrm{PhD}$ dissertation submitted to the Faculty of the Virginia Polytechnic Institute and State University, Blacksburg, VA.

Leventhal, G.S. (1980), "What should be done with equity theory? New approaches to the study of fairness in social relationships", in Gergen, K., Greenberg, M. and Willis, R. (Eds), Social Exchange: Advances in Theory and Research, Plenum Press, New York, NY, pp. 27-55.

McDowall, A. and Fletcher C. (2004), "Employee development: an organizational justice perspective", Personnel Review, Vol. 33 No. 1, p. 8.

Niehoff, B.P. and Moorman, R.H. (1993), "Justice as a mediator of the relationship between methods of monitoring and organizational citizenship behavior", Academy of Management Journal, Vol. 36 No. 3, pp. 527-56.

Randeree, K., Malik, I. (2008), "Models for Leading with Organizational Justice: Equitable Management of the Human Resource in Diverse Environments", The International Journal of Diversity in Organisations, Communities and Nations, Vol. 7, No. 6, pp. 65-69.

Robinson, K. (2004), "The impact of individual differences on the relationship between employee perceptions of organizational justice and organizational outcome variables", $\mathrm{PhD}$ dissertation, Alliant International University, San Diego, CA.

Shenhar, A. (1993), "Keeping management's door open: how to establish an open-door policy that works", Leadership \& Organisation Development Journal, Vol. 14 No. 2, pp. 8-12.

Stark, E., Thomas, L. and Poppler, P. (2000), "Can personality matter more than justice? A study of downsizing and layoff survivors in the USA and implications for cross cultural study", paper presented to the Academy of Business and Administrative Sciences International Conference, Prague.

Tang, L. and Sarsfield-Baldwin, L. (1996), "Distributive and procedural justice as related to satisfaction and commitment", SAM Advanced Management Journal, Vol. 61 No. 3, pp. 25-31. 
Tang, T. and Fuller, R. (1995), "Job satisfaction in joint venture hotels in China: an organizational justice analysis", SAM Advanced Management Journal, Vol. 60 No. 4, pp. 12-16.

Yin, R.K. (1994), "Case Study Research, Design and Methods", 2nd edition, Thousand Oaks: Sage Publications, Inc.

\section{Appendix}

\section{Questionnaire}

\section{Important notes:}

- The purpose is of this survey is to study the impact of Organisational Justice on the job performance of unskilled workers in Dubai.

- The questionnaire scales all the questions on a range of 1 to 5 . The value of ' 1 ' stands for lowest influence/importance, whereas ' 5 ' shows greatest important/influence for the candidate.

- The organisational justice measures developed by Niehoff and Moorman were used to test their impact on employee performance and job satisfaction amongst the unskilled workers

- The population of this study comprised unskilled workers, domestic helpers and workers within facility management industry.

- Data were collected from employees working in the Dubai, in some cases questionnaires were translated into Tamil and Hindi language. Descriptive statistics was used to examine the data.

\subsection{General Information}

Nationality group: $\square$ Western National $\square$ Arab National $\quad \square$ Indian sub-continent
$\square$ Far East Asia
$\square$ Other

Gender: $\square$ Male $\quad \square$ Female

Age: $\square 21-25 \quad \square 26-30 \quad \square 31-35 \quad \square 36-45 \quad \square$ 46-55 $\square>55$

Education: $\square$ Elementary School $\square$ High School $\square$ Diploma $\square$ Graduate $\square$ P. Grad

Work Experience: $\square$ 0-3 years $\square$ 4-5 years $\square$ 6-10 years $\square 10$-15 years $\square 16-20$ years $\square$ 20-30 years $\quad \square>30$ years

Gross Average Monthly Income: $\square$ Less than AED $500 \quad \square$ AED 501-700 $\square$ AED 701-900

$\square$ AED 901-1100 $\square$ AED 1101-1300 $\square$ More than 1300

Marital Status: $\quad \square$ Single $\square$ Married $\square$ Divorced

Number of Dependants: $\square$ None $\square$ 1-3 $\square$ 4-5 $\square$ Over 5

Financial Liability: $\square$ Yes $\square$ No

Total Number of Earning Members In the Family: $\square 1 \quad \square 2 \quad \square 3$ or More

Job description in the company:

Country of Origin - Company: $\square$ Western $\square$ Arab $\quad \square$ Indian sub-continent

$\square$ Far East Asia

$\square$ Other

Any Additional Comments: 


\subsection{Impact of Distributive Justice on the Job Performance}

\subsection{Organisational Justice}

2.1 Impact of Distributive Justice on the Job Performance

\begin{tabular}{|l|l|l|l|l|l|}
\hline & $\begin{array}{l}\text { Strong y } \\
\text { Agree }\end{array}$ & $\begin{array}{l}\text { Somewhat } \\
\text { Agree }\end{array}$ & Neutra & $\begin{array}{l}\text { Somewhat } \\
\text { D sagree }\end{array}$ & $\begin{array}{l}\text { Strong y } \\
\text { D sagree }\end{array}$ \\
\hline My work schedule is fair & 1 & 2 & 3 & 4 & 5 \\
\hline I think my level of pay is fair & 1 & 2 & 3 & 4 & 5 \\
\hline I consider my workload to be fair & 1 & 2 & 3 & 4 & 5 \\
\hline Overall the rewards I receive here are quite fair & 1 & 2 & 3 & 4 & 5 \\
\hline I feel that my job responsibilities are fair & 1 & 2 & 3 & 4 & 5 \\
\hline
\end{tabular}

\subsection{Impact of Procedural Justice on the Job Performance}

\begin{tabular}{|l|l|l|l|l|l|}
\hline & $\begin{array}{l}\text { Strong y } \\
\text { Agree }\end{array}$ & $\begin{array}{l}\text { Somewhat } \\
\text { Agree }\end{array}$ & Neutra & $\begin{array}{l}\text { Somewhat } \\
\text { D sagree }\end{array}$ & $\begin{array}{l}\text { Strong y } \\
\text { D sagree }\end{array}$ \\
\hline $\begin{array}{l}\text { Job decisions are made by the manager in an } \\
\text { unbiased manner }\end{array}$ & 1 & 2 & 3 & 4 & 5 \\
\hline $\begin{array}{l}\text { My manager makes sure that all employee } \\
\text { concerns are heard before job decisions are } \\
\text { made }\end{array}$ & 1 & 2 & 3 & 4 & 5 \\
\hline $\begin{array}{l}\text { To make job decisions my manager clarifies } \\
\text { decisions and provides additional information } \\
\text { when requested by the employee. }\end{array}$ & 1 & 2 & 3 & 4 & 5 \\
\hline $\begin{array}{l}\text { All job decisions are applied consistently across } \\
\text { all affected. }\end{array}$ & 1 & 2 & 3 & 4 & 5 \\
\hline $\begin{array}{l}\text { Employees are allowed to challenge or appeal job } \\
\text { decisions made by the manager. }\end{array}$ & 1 & 2 & 3 & 4 & 5 \\
\hline
\end{tabular}

\subsection{Impact of Interactional Justice on the Job Performance}

\begin{tabular}{|l|l|l|l|l|l|}
\hline & $\begin{array}{l}\text { Strong y } \\
\text { Agree }\end{array}$ & $\begin{array}{l}\text { Somewhat } \\
\text { Agree }\end{array}$ & Neutra & $\begin{array}{l}\text { Somewhat } \\
\text { D sagree }\end{array}$ & $\begin{array}{l}\text { Strong y } \\
\text { D sagree }\end{array}$ \\
\hline $\begin{array}{l}\text { When decisions are made about my job, the } \\
\text { manager treats me with kindness and } \\
\text { consideration. }\end{array}$ & 1 & 2 & 3 & 4 & 5 \\
\hline $\begin{array}{l}\text { When decisions are made about my job, the } \\
\text { manager treats me with respect and dignity }\end{array}$ & 1 & 2 & 3 & 4 & 5 \\
\hline $\begin{array}{l}\text { When decisions are made about my job, the } \\
\text { manager is sensitive to my personal needs. }\end{array}$ & 1 & 2 & 3 & 4 & 5 \\
\hline $\begin{array}{l}\text { When decisions are made about my job, the } \\
\text { manager deals with me in a truthful manner. }\end{array}$ & 1 & 2 & 3 & 4 & 5 \\
\hline $\begin{array}{l}\text { When decisions are made about my job, the } \\
\text { manager shows concern for my rights as an } \\
\text { employee. }\end{array}$ & 1 & 2 & 3 & 4 & 5 \\
\hline $\begin{array}{l}\text { Concerning decisions made about my job, the } \\
\text { manager discusses the implications of the } \\
\text { decisions with me }\end{array}$ & 1 & 2 & 3 & 4 & 5 \\
\hline $\begin{array}{l}\text { The manager offers adequate justification for } \\
\text { decisions made about my job. }\end{array}$ & 1 & 2 & 3 & 4 & 5 \\
\hline $\begin{array}{l}\text { When making decisions about my job, the } \\
\text { manager offers explanations that make sense to } \\
\text { me. }\end{array}$ & 1 & 2 & 3 & 4 & 5 \\
\hline $\begin{array}{l}\text { My manager explains very clearly any decision } \\
\text { made about my job. }\end{array}$ & 1 & 2 & 3 & 4 & 5 \\
\hline
\end{tabular}




\subsection{Job Performance}

3.1 Impact of Organisational Justice on Job Performance

\begin{tabular}{|l|l|l|l|l|l|}
\hline & $\begin{array}{l}\text { Strong y } \\
\text { Agree }\end{array}$ & $\begin{array}{l}\text { Somewhat } \\
\text { Agree }\end{array}$ & Neutra & $\begin{array}{l}\text { Somewhat } \\
\text { D sagree }\end{array}$ & $\begin{array}{l}\text { Strong y } \\
\text { D sagree }\end{array}$ \\
\hline $\begin{array}{l}\text { I consider my performance better that the } \\
\text { average employee in this firm. }\end{array}$ & 1 & 2 & 3 & 4 & 5 \\
\hline I always reach my performance targets. & 1 & 2 & 3 & 4 & 5 \\
\hline $\begin{array}{l}\text { I feel that my performance is reflective of my } \\
\text { abilities. }\end{array}$ & 1 & 2 & 3 & 4 & 5 \\
\hline Overall, I am a very good performer. & 1 & 2 & 3 & 4 & 5 \\
\hline $\begin{array}{l}\text { I feel that my job conditions are not allowing me } \\
\text { to perform at high levels }\end{array}$ & 1 & 2 & 3 & 4 & 5 \\
\hline
\end{tabular}


